\title{
The impact of urban areas on the water quality gradient along a lowland river
}

\author{
Katarzyna Glińska-Lewczuk • Iwona Golaś (D) Józef Koc • \\ Anna Gotkowska-Plachta • Monika Harnisz • \\ Andrzej Rochwerger
}

Received: 15 February 2016/Accepted: 10 October 2016 / Published online: 18 October 2016

(C) The Author(s) 2016. This article is published with open access at Springerlink.com

\begin{abstract}
The effects of five towns on river water pollution were examined along the Lyna River (southern watershed of the Baltic Sea, northern Poland). The relationships among the spatially derived indicators of urbanization, environmental variables, and physicochemical and microbiological data (heterotrophic plate count at 22 and $37{ }^{\circ} \mathrm{C}$, and fecal coli) obtained from longitudinal river profiling have been examined with the use of multivariate analyses such as principal component analysis with factor analysis (PCA/FA) and hierarchical cluster analysis (HCA). We recognized the river channel as an environmental path that links serial urban areas into an "urban river continuum." An overall increasing trend in nutrients and indicator bacteria from suburban headwaters to urbanized sections of the river was detected despite a significant decrease in those between the towns. We concluded that the role of a multicity is equally as important as a single urban area in predicting the impacts of man-made pollutants on river water quality.
\end{abstract}

I. Gołaś $(\bowtie) \cdot$ A. Gotkowska-Płachta $\cdot$ M. Harnisz Department of Environmental Microbiology, University of Warmia and Mazury in Olsztyn, Prawocheńskiego 1, 10-759 Olsztyn, Poland

e-mail: iwonag@uwm.edu.pl

K. Glińska-Lewczuk · J. Koc · A. Rochwerger

Department of Water Resources, Climatology, and Environmental Management, University of Warmia and Mazury in Olsztyn, Plac Lodzki 2, 10-759 Olsztyn, Poland
Keywords Lowland river. Urban area - Water quality . Microbiological pollution

\section{Introduction}

Rivers, being a natural interface between watersheds and the seas, are a medium that transports both substances of natural origin and pollutant loads from anthropogenic sources. Among various human activities within their watersheds, urban areas are reported to have the most consistent and ubiquitous effects on surface water quality (Potasznik and Szymczyk 2015; Mallin et al. 2016), habitat alteration (Hatt et al. 2004; Elmore and Kaushal 2008), and reduction in biodiversity (Spänhoff et al. 2007; Obolewski 2013) due to both the significant load of pollutants from point and non-point sources and the increased impervious surface cover. Direct runoff from urbanized surfaces and sewage discharges not connected to a wastewater treatment plant (WWTP) has emerged as a serious threat, not only to the ecological values of water ecosystems but also to the provision of good quality water required for all socioeconomic functions (Kaushal and Belt 2012; Brion et al. 2015; Gotkowska-Płachta et al. 2016). The observations of ecological degradation of streams draining urban lands enabled Walsh et al. (2005) to formulate the term "urban stream syndrome," which means negative changes in flow regime, riverbed morphology, and increase in pollutants' loads. Although the mechanisms driving the syndrome are 
complex, the most significant impacts reported in the literature refer primarily to the imperviousness of the total catchment area (Walsh et al. 2012) and stormwater runoff delivered to streams by urban drainage systems (Kaushal and Belt 2012). In light of these factors, the considerable monitoring regarding the seasonal variation of environmental factors (temperature, precipitation, and flows) on the physico-chemical and microbiological properties of urban streams has been reported (Brooks et al. 2006, Schoonover et al. 2006, Walsh et al. 2016).

Although the impact of urban pollution on aquatic ecosystems has been well described in the literature (e.g., Servais et al. 2007; Daly et al. 2013; GarciaArmisen et al. 2014; Begum et al. 2016), few studies regarding the significance of consecutive towns located along one river on water pollution have been carried out. In the present study, we monitored the changes in water quality parameters in a lowland river passing through five towns with a dynamic conceptual framework for investigating important research questions: (i) how do the water quality parameters, including nutrients and bacteria, change in space and time under environmental site-specific factors such as flow rate, precipitation, and anthropogenic variables due to the input of wastewater or population size connected to WWTPs?; (ii) what is the gradient of river pollution along the river course passing through the urban areas?; and (iii) what are the overlapping (cumulative) effects of urban pollution on water quality in the receiving river or the potential for self-purification downstream of the urban areas? We hypothesized that the river water pollution is related to the anthropogenic activities along the river and that consecutive towns may have a cumulative or overlapping effect on the river's functions. Based on hydrochemical and microbiological profiling along the river course, we applied data reduction techniques as principal component analysis and factor analysis (PCA/FA) to evaluate the importance of various water quality parameters and determine the most meaningful parameters responsible for the spatial and temporal variations in river water quality. Finally, the objective of this study was to quantify the seasonal and spatial distribution of common indicator bacteria, including heterotrophic psychrophilic bacteria (HPC 22), heterotrophic mesophilic bacteria (HPC 37), and fecal coliforms (FC), along a lowland postglacial river located in the temperate climate zone under the pressure of urban development.

\section{Methods}

Site description

River corridors in northeastern Poland (region called the "Green Lungs of Poland") are widely perceived to be of high ecological quality, with flow regimes typical of temperate climate zones in the Middle European lowlands. The Łyna River is the main watercourse in the region in terms of the total catchment area $\left(7126 \mathrm{~km}^{2}\right)$ and total length $(264 \mathrm{~km})$ (Fig. 1). The river originates from a headwater area (263 $\mathrm{km}$ from the river mouth) at a height of $155 \mathrm{~m}$ a.s.l. This section of the river shows outstanding natural values with limited human activity. The catchment is located in postglacial area with mosaics of soils, with feature characteristic of morainic hills used by agriculture $(53 \%)$, forests $(29 \%)$, lakes $(7 \%)$, and built-up areas (11\%) (Glińska-Lewczuk and Burandt 2011). The agricultural areas in the region are used by private farmers. Soils are typically fertilized with $\mathrm{N}$ inorganic salts $\left(\mathrm{KNO}_{3}\right)$ with a load of 110 $124 \mathrm{~kg} \mathrm{NPK} \mathrm{ha}^{-1}$ year $^{-1}$, including N as $75.1 \mathrm{ha}^{-1}$ year $^{-1}$ (GUS 2012). The high retention indices of its catchment result from the numerous lakes, prevailing sharing of permeable soils, and dense forest cover, which attenuates any flood wave in its upper course (GlińskaLewczuk 2006).

The average river flow at the gauge in Sepopol (Polish-Russian border) in the study period (November 2011-October 2012) was $23.4 \mathrm{~m}^{3} \mathrm{~s}^{-1}$, ranging from $13.3 \mathrm{~m}^{3} \mathrm{~s}^{-1}$ during the summer low water period to $62.8 \mathrm{~m}^{3} \mathrm{~s}^{-1}$ during spring floods. The runoff per unit area is generally low $\left(5-7 \mathrm{~L} \mathrm{~km}^{-2} \mathrm{~s}^{-1}\right)$ due to moderate rainfall totals (620 $\mathrm{mm}$ on average) and high evapotranspiration values $(570 \mathrm{~mm})$. According to the Institute for Meteorology and Water Management in Poland (IMWM), the study period (2012) cover the wet year with rainfall sums which exceeded the multiyear average and amounted to $738 \mathrm{~mm}$ in Olsztyn and $783 \mathrm{~mm}$ in Lidzbark Warmiński.

At a distance of ca. $45 \mathrm{~km}$ from the springs, the Łyna River reaches Olsztyn - the first of the five towns on its way. The total urban area (towns on the Łyna River) covers $122.74 \mathrm{~km}^{2}$, which is $2.15 \%$ of its catchment within the Polish border. The town of Olsztyn is the most populated 


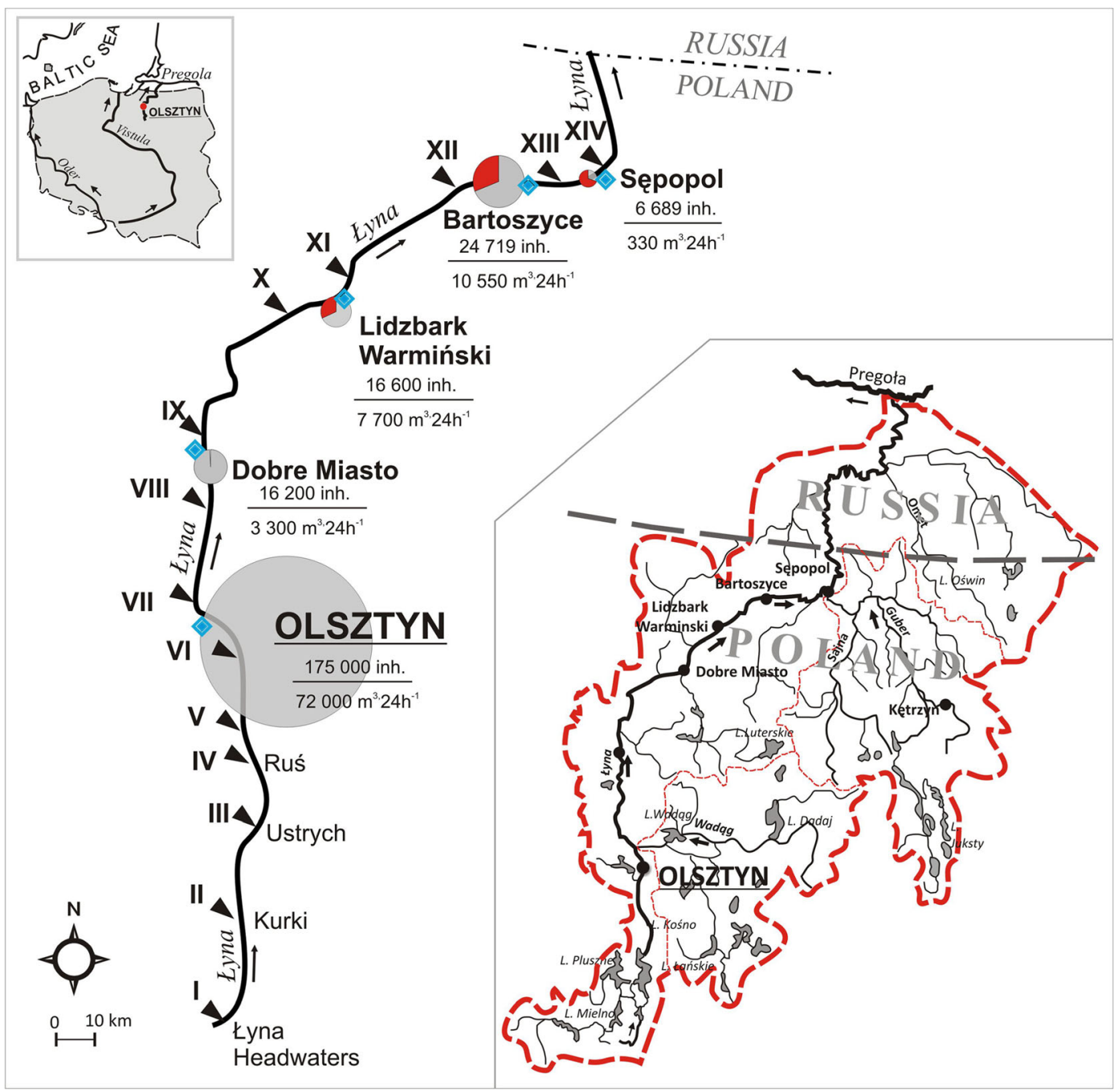

Fig. 1 Location of the study area on the background of the Łyna River catchment. Sampling stations $(I-X I V)$ are marked along the Łyna River with black triangles. The size of a circle is related to the population in the town. Gray color in the circle denotes inhabitants served by the wastewater treatment plants (WWTP), whereas red color denotes a share of inhabitants not served by the WWTP. Blue diamond symbol denotes WWTP placement. The upper number in a fraction denotes the population in the town, while the lower number is the daily flow rate of the WWTP

of the population connected to the sanitary network ranges from $68 \%$ for Dobre Miasto to $100 \%$ for Olsztyn. The remaining population uses septic systems or a home sewage treatment plants.

Water sampling and analytical procedure

The present study was conducted from November 2011 to October 2012 along a 198-km section of the Łyna River within the Polish border. Water sampling was carried out on a bimonthly basis from 14 sampling stations (Fig. 1; Table 1) established along both natural (Journal of Laws of 2006, no. 137, item 984). The share 


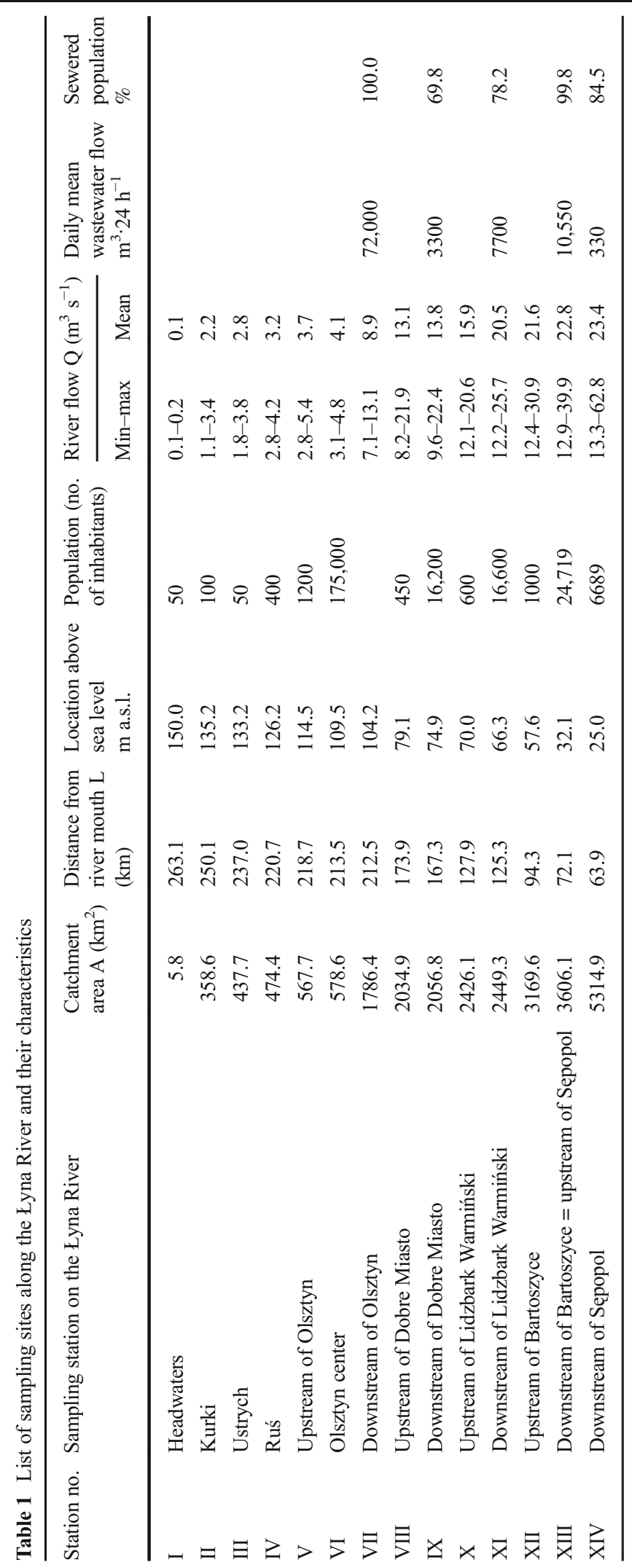


(upstream Olsztyn) and urban (downstream Olsztyn) sections of the river. The sampling design aimed to reflect the spatial and seasonal variations in the chemical composition of water, with special emphasis on the effects of urban areas on the river's health. All samples were taken upstream of each town and downstream, ca. $200 \mathrm{~m}$ beneath the WWTP effluents, to avoid influence from the river tributaries.

Water temperature $\left({ }^{\circ} \mathrm{C}\right)$, dissolved oxygen (DO, $\mathrm{mg} \mathrm{L}^{-1}$ ), and $\mathrm{pH}$ were recorded in situ using the calibrated multiparameter probe YSI Professional Plus, USA. The water samples were collected in 5L sterile polyethylene bottles and kept cold in the dark until they were analyzed within $12 \mathrm{~h}$. The laboratory analyses of the water included the following nutrients: nitrate nitrogen $\left(\mathrm{NO}_{3}-\mathrm{N}\right)$, nitrite nitrogen $\left(\mathrm{NO}_{2}-\mathrm{N}\right)$, ammonia nitrogen $\left(\mathrm{NH}_{4}-\mathrm{N}\right)$, and orthophosphate $\left(\mathrm{PO}_{4}-\mathrm{P}\right)$; the total phosphorus (TP) and the chemical oxygen demand (COD) were used as determinants of organic matter concentrations. The analyses followed the methods described in the Standard Methods (APHA 1998). In an attempt to devise a system to compare various parts of the Lyna River sections, we applied the Water Quality Index (WQI) in a modification of the original Scottish Water Quality Index (House 1989) and adapted by Cymes and Glińska-Lewczuk (2016) to low-gradient watercourses in northeastern Poland. The WQI, as one of the most widely used water quality procedures, allows for the determination of a potential economic use of water, which in itself is an important instrument to be employed in water management (dos Santos Simoes et al. 2008). The nine-parameter index is based on an aggregation of three groups of parameters: physical (temperature, conductivity, total suspended solids), chemical (dissolved oxygen $\mathrm{pH}$, ammonia, nitrate), and organic (biological oxygen demand, chemical oxygen demand). All data were $\log _{10}$ transformed to standardize the data to a mean of 0 and a standard deviation of 1 to eliminate scale biases.

The microbial analysis of the water samples aimed to determine the following: heterotrophic plate count at $22{ }^{\circ} \mathrm{C}$ (HPC 22) such as autochthonous microorganisms, heterotrophic plate count at $37{ }^{\circ} \mathrm{C}$ (HPC 37), and fecal coliforms (FC) such as allochthonous microorganisms. Heterotrophic plate counts of bacteria (HPC 22, HPC 37) were determined in tryptic soy agar (TSA) (Oxoid) by plate count according to the Standard Methods (APHA 1998). To reduce the bacterial density, a decimal dilution series with PBS was prepared. Subsequently, $0.1 \mathrm{~mL}$ each of the well-homogenized solution (of the respective sample dilutions from $10^{-1}$ to $10^{-4}$ ) was placed on a TSA medium. Each sample was plated in duplicate and incubated for $24 \mathrm{~h}$ at $35 \pm 2{ }^{\circ} \mathrm{C}$ (HPC 37) and $72 \mathrm{~h}$ at $22 \pm 2{ }^{\circ} \mathrm{C}$ (HPC 22). Plates of those dilutions that yielded $30-300$ colonies were chosen; the cultured colonies were counted and reported as colony forming units per milliliter of water $\left(\mathrm{CFU} \mathrm{mL} \mathrm{m}^{-1}\right)$.

To calculate the FC counts, the water samples were filtered using $0.45-\mathrm{mm}$ pore size, $47-\mathrm{mm}$ diameter sterile cellulose nitrate filters by "Sartorius." Subsequently, the filters were placed on mFC agar (Difco) supplemented with $1 \%$ rosolic acid, a selective medium specifically formulated for the enumeration of fecal coliforms by the membrane filtration method without prior enrichment according to the Standard Methods (APHA 1998). All the samples were incubated at $44.5{ }^{\circ} \mathrm{C}$ for $18-24 \mathrm{~h}$. From each water sample, representative unique isolates, including a range of blue colonies, were randomly selected from the FC plates (Wohlsen 2011). Selected isolates, classified by this selection process as total thermotolerant fecal coliforms (FC), were enumerated and reported as the means of triplicate samples (total CFU $100 \mathrm{~mL}^{-1}$ ).

Hydrological and meteorological data acquisition

Water flow data for the Lyna River during the observation period (hydrological year 2012) at Olsztyn (V), Smolajny (downstream of Dobre Miasto, IX), and Sępopol (XIV) have been provided by the IMWM in Poland. River flows for the stations X-XIII result from the calculations of IMWM data using the HEC-RAS software (HECRAS 2010). The software uses one-dimensional hydraulic analysis components for flow water surface profile computations.

The flows at stations I-IV were measured at the same time as the water sampling with an electromagnetic flow velocity sensor (Valeport, UK). The flow was calculated using the standard velocityarea method. Precipitation and related meteorological data for the region over the study period were 
measured at an automatic weather station network belonging to the University of Warmia and Mazury in Olsztyn, Poland.

Data analysis and statistical methods

To assess the statistical differences among sampling locations for the water quality data and environmental data (seasons and flows), a non-parametric analysis of the variance Kruskal-Wallis $(\mathrm{K}-\mathrm{W})$ and Dunn's tests as post hoc procedures $(P \leq 0.05)$ was performed using the statistical software STATISTICA 10.0 PL. The Wilcoxon paired-sample test (Zar 1984) was used to compare paired water quality measurements upstream and downstream of each town.

The impact of environmental factors on the studied parameter concentrations in the analyzed water samples was determined by principal component analysis (PCA) with the use of the CANOCO 4.5 software package (ter Braak and Šmilauer 2002). PCA has allowed for the identification of the spatial (pollution from municipal origin) and temporal (seasons and flows) reduced factors affecting the quality of river water and the indication of polluting sources. The share of a given physico-chemical parameter in each season was graphically presented using a pie chart.

The varimax rotation method was used to apply factor analysis (FA). The main purpose of FA was to reduce the contribution of less significant variables and to further simplify the data structure that comes from PCA. The factor loading values were classified according to Liu et al. (2003) as "strong," "moderate," and "weak," corresponding to absolute loading values of $>0.75,0.75-0.50$, and $0.50-0.30$, respectively.

Hierarchical cluster analysis (HCA) was used to investigate the grouping of the sampling sites along the Lyna River. Ward's method using squared Euclidean distances was used as a measure of the similarity (Shrestha and Kazama 2007). The dendrogram was used to interpret the results of the cluster analysis. The spatial variability of water quality was determined from HCA using the linkage distance, reported as $\mathrm{D}_{\text {link }} / \mathrm{D}_{\text {max }}$. The quotient was then multiplied by 100 to standardize the linkage distance represented on the $x$-axis (Singh et al. 2005).

\section{Results and discussion}

Discontinuity in the longitudinal profile of the Łyna River

\section{Physicochemical parameters}

The water quality parameters varied markedly within and among the sampling stations along the Łyna River. The Łyna River water, like most of the other postglacial watercourses, is neutral to alkaline in nature and shows medium mineralization (ca. $600 \mu \mathrm{S} \mathrm{cm}{ }^{-1}$ ) with dominating $\mathrm{Ca}^{2+}$ and $\mathrm{HCO}_{3}{ }^{-}$ions in its overall chemical composition (Glińska-Lewczuk 2006). Based on hydrochemical profiling performed along the Łyna River, we have marked off two significant sections in a longitudinal profile of the river with a breaking point at Olsztyn - the biggest urban area in its catchment. The river upstream of Olsztyn represents natural values, not exposed to human activity, while the river downstream of Olsztyn is directly exposed to both urban and agricultural land use, which contributes to the extensive use of water and, therefore, its pollution. The river transit through the five towns (sampling stations between Olsztyn and Sępopol (VI-XIV) is represented by significantly higher values for the majority of the water quality parameters when compared to those in the upper river section (upstream of Olsztyn (I-V)).

DO showed large fluctuations with a clear decreasing trend in water aeration from $7.70 \mathrm{mg} \mathrm{L}^{-1}$ in the headwaters to $6.43 \mathrm{mg} \mathrm{L}^{-1}$ upstream of Olsztyn (Table 2). As expected, the DO concentrations decreased to less than $5.0 \mathrm{mg} \mathrm{L}^{-1}$ in the summer (not shown in the tables) at every station, but severe oxygen deficits only appeared at stations downstream of the cities, which could explain the stated variability. Consequently, in the "urban" section, the river water was characterized by low mean values of $\mathrm{NO}_{3}-\mathrm{N}\left(0.08-0.38 \mathrm{mg} \mathrm{L}^{-1}\right)$ and relatively high values of $\mathrm{NH}_{4}-\mathrm{N}\left(0.15-0.62 \mathrm{mg} \mathrm{L}^{-1}\right)$ (Table 2). An almost 4-fold increase in the mean $\mathrm{NH}_{4}-\mathrm{N}$ concentration was observed downstream of the WWTP in Olsztyn (VII) when compared to the Olsztyn center (VI). The concentrations of parameters such as $\mathrm{NO}_{2}-$ $\mathrm{N}, \mathrm{NH}_{4}-\mathrm{N}, \mathrm{TP}, \mathrm{PO}_{4}-\mathrm{P}$, and $\mathrm{COD}$ were significantly lower at stations $\mathrm{I}-\mathrm{V}$ than at stations VI-XIV $(\mathrm{K}-\mathrm{W}$ test; $P=0.0001$ ). However, $\mathrm{DO}$ and $\mathrm{NO}_{3}-\mathrm{N}$ showed opposite characteristics. They were significantly higher in the upper section than in the lower section $(\mathrm{K}-\mathrm{W}$ test; $P=0.0001)$. A significant drawdown effect on 


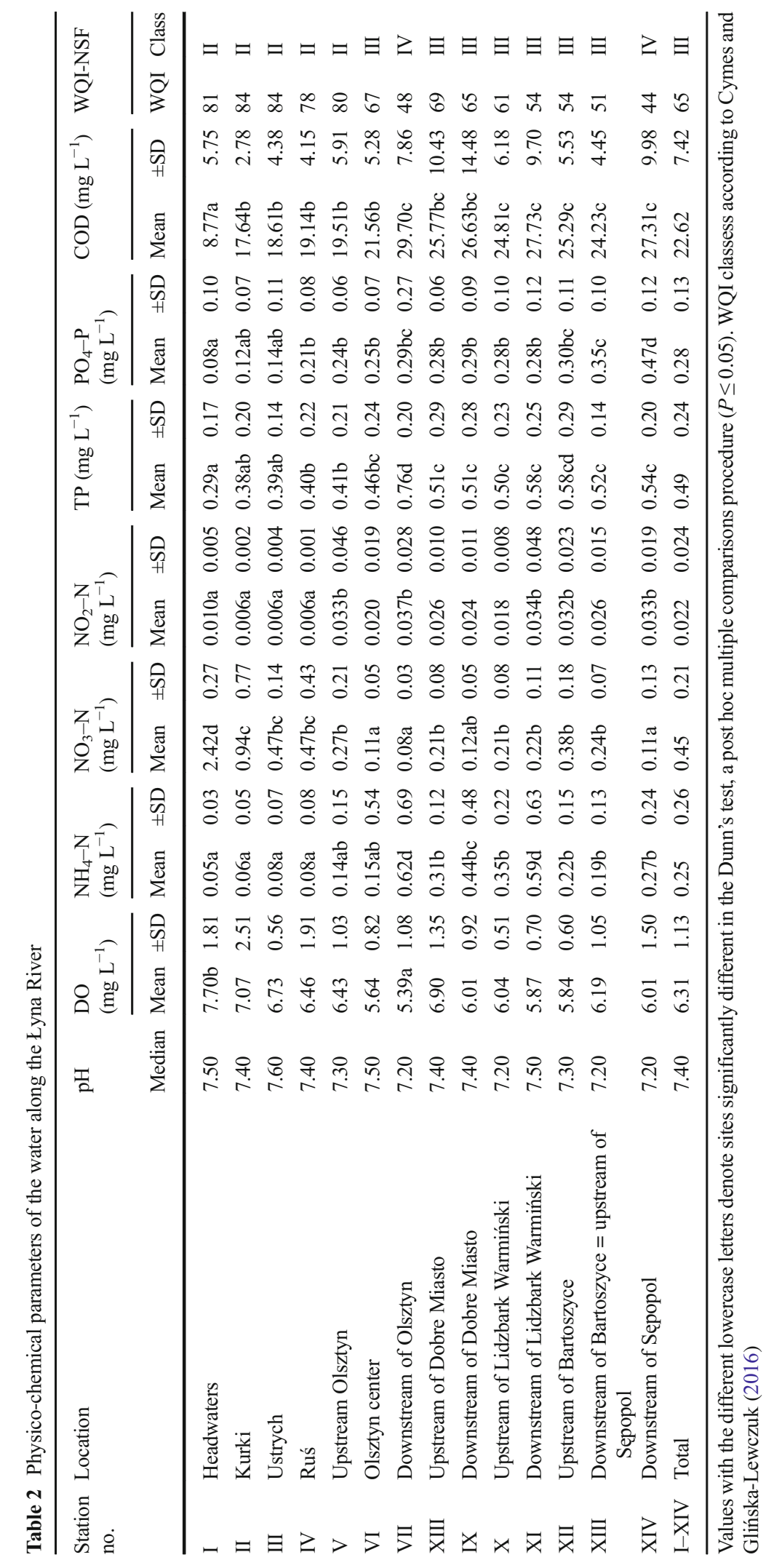


dissolved oxygen in the river water beneath Olsztyn is likely to have ammonium oxidation and the decomposition of organic matter, which brings potentially harmful consequences for aerobic biota (Daniel et al. 2002). The high level of $\mathrm{NH}_{4}-\mathrm{N}$ concentration level likely stimulated the growth of nitrifying bacteria. Our results indicate that the pollution of the Łyna River with $\mathrm{NH}_{4}-$ $\mathrm{N}$ downstream of Olsztyn or Lidzbark Warmiński facilitated the growth of nitrifying bacteria inoculated by the wastewater effluents. In general, the inorganic $\mathrm{N}$ species concentrations in the Lyna River were much less than $10 \mathrm{mg} \mathrm{L}^{-1}$, which was the US Environmental Protection Agency's drinking water standard (US EPA 1986) or the EU's directive for bathing (Directive 2006/7/EC).

Phosphates showed a gradually increasing pattern along the whole river length. Along the natural upper river region $(\mathrm{I}-\mathrm{V})$, the mean concentrations of $\mathrm{PO}_{4}-$ $\mathrm{P}$ did not exceed $0.22 \mathrm{mg} \mathrm{L}^{-1}$ and $75 \%$ of the samples contained less than $0.1 \mathrm{mg} \mathrm{L}^{-1}$, which is the concentration limit for streams recommended by US EPA (1986) to prevent excessive algal growth. In the urbanized river section, high concentrations of phosphate $(\mathrm{P})\left(>0.1 \mathrm{mg} \mathrm{L}^{-1}\right)$ were recorded in $100 \%$ of the samples. The maximal values of phosphate $(\mathrm{P})$ with a mean of $0.47 \mathrm{mg} \mathrm{L}^{-1}$ showed the samples taken downstream of Sepopol (at the Polish-Russian border). Downstream of the WWTP in Olsztyn (VII), both TP and COD showed significant increases (Dunn's test, $P \leq 0.05$ ) in their mean values to 0.76 and $29.70 \mathrm{mg} \mathrm{L}^{-1}$, respectively. In the longitudinal profile of the Lyna River, COD $<20 \mathrm{mg} \mathrm{L}^{-1}$ was attributed to unpolluted river regions, while all the sampling stations along the urban regions exceeded that value.
Serial urban areas along the Lyna River have a deteriorating effect on the overall water quality, which is reflected by the WQI. All the sampling stations along the unpolluted stretch of the Lyna River are characterized by very good quality WQI ratings, with mean scores $>80$ points (Table 2). Stations located downstream of the towns had significantly lower WQI values (44-65) when compared to the stations located upstream of the towns (51-80). Except for the station located downstream of the WWTPs in Olsztyn (WQI = 48) and Sępopol (WQI $=44)$, no bad rating for water quality was recorded. The differences in the WQI ratings showed that the Łyna River can be divided into two sections composed of stations I-V (class II) and stations VI-XIV (classes III-IV). It has been reported (Heidenwag et al. 2001; Vaikasas and Dumbrauskas 2010) that rivers with slopes $<1 \%$ and thus lower velocities seem to have higher potential for self-purification, as they maintain the natural retention threshold for pollutants. The evidence for the self-purification potential of the Łyna River within its "urban section" might be a gradual decrease in the nutrient concentrations between the towns, which resulted from small slopes of the river channel $(0.12-1.46 \%$ o). Within a distance of $38 \mathrm{~km}$ between Olsztyn (VII) and Dobre Miasto (VIII), with no lateral input from point sources, the concentrations of $\mathrm{NH}_{4}-\mathrm{N}$ decreased by $50 \%, \mathrm{PO}_{4}-$ $\mathrm{P}$ by $40 \%$, and $\mathrm{NO}_{2}-\mathrm{N}$ and TP by $30 \%$.

This overall pattern for the physico-chemical parameters used in this study indicates significant contributions from the most populated towns toward the deterioration of river water quality, in spite of the modern WWTPs (Table 3). Two of the five towns located on the Łyna River significantly changed the river water quality,

Table 3 Wilcoxon paired-test between the overall water quality in the samples taken from (A) natural sections and (B) urbanized sections of the Łyna River upstream and downstream of the towns along the Łyna River

\begin{tabular}{|c|c|c|c|c|c|c|c|}
\hline \multicolumn{2}{|c|}{ Location along the Łyna River } & \multicolumn{2}{|c|}{ Sampling stations compared } & \multirow{2}{*}{$\frac{N}{96}$} & \multirow{2}{*}{$\frac{T}{888}$} & \multirow{2}{*}{$\frac{Z}{2.39}$} & \multirow{2}{*}{$\frac{P \text { value }}{0.017^{*}}$} \\
\hline (A) Natural section & & Headwaters (I) & Ruś (IV) & & & & \\
\hline & & Headwaters (I) & Olsztyn (VI) & 96 & 870 & 2.64 & $0.008^{* *}$ \\
\hline \multirow[t]{5}{*}{ (B) Urbanized section } & Olsztyn & Upstream (V) & Downstream (VII) & 96 & 704 & 3.93 & $0.000 * * *$ \\
\hline & Dobre Miasto & Upstream (VIII) & Downstream (IX) & 94 & 1293 & 0.70 & 0.484 \\
\hline & Lidzbark Warmiński & Upstream (X) & Downstream (XI) & 92 & 548 & 4.41 & $0.000 * * *$ \\
\hline & Bartoszyce & Upstream (XII) & Downstream (XIII) & 94 & 1182 & 1.45 & 0.146 \\
\hline & Sępopol & Upstream (XIII) & Downstream (XIV) & 96 & 963 & 1.81 & 0.071 \\
\hline
\end{tabular}

$N$ number of samples, $T$ test statistics, $Z$ normal approximation

$* P \leq 0.05 ; * * P \leq 0.01 ; * * * P \leq 0.001$ 
namely, Olsztyn and Lidzbark Warmiński (Wilcoxon paired-test, $P=0.0001$ ).

\section{Microbiological parameters}

The bacterial colonies at stations I to IV formed a deeply branching group (Fig. 2), reflecting a differentiation in the physico-chemical parameters along the longitudinal dimension of the Łyna River. In the river's upper region, comparing the HPC 22 in water from the first sampling station (I) with that from subsequent stations (II-IV) showed its relationship with increasing distance from the headwaters (Fig. 2a). The mean bacteria counts from this group ranged from less than $0.1 \times 10^{3} \mathrm{CFU} \mathrm{mL}^{-1}$ to less than $2 \times 10^{3} \mathrm{CFU} \mathrm{mL}^{-1}$ and showed no significant difference among the stations (K-W test; $p=0.0001)$. In the urbanized regions, the mean counts of HPC 22 ranged from $2.4 \times 10^{3} \mathrm{CFU} \mathrm{mL}^{-1}$ at Sępopol to $7.98 \times 10^{3} \mathrm{CFU} \mathrm{mL}^{-1}$ at Lidzbark Warmiński. In general, these bacteria were less numerous in water samples collected upstream than downstream of the towns; however, only the examples from Lidzbark Warmiński and Sepopol showed statistical significance (K-W and post hoc Dunn's tests, $P \leq 0.05$ ).

The HPC 37 differed by several orders of magnitude with regard to the section, sampling station, and season. Throughout the entire study period, the lowest HPC 37 values were noted in water samples collected from sampling stations I-IV. They ranged from $0 \mathrm{CFU} \mathrm{mL}^{-1}$ in the headwaters (I) to $0.4 \times 10^{3} \mathrm{CFU} \mathrm{mL}^{-1}$ at Ustrych (III) and Ruś (IV). Higher bacterial concentrations were found in the water samples collected along the urban section of the river, in particular, at the stations located downstream of the towns (VI, VII, IX, XI, XII, and XIV). The mean counts of HPC 37 ranged from $0.3 \times 10^{3} \mathrm{CFU} \mathrm{\textrm {mL } ^ { - 1 }}$ upstream of Lidzbark Warmiński (X) to $3 \times 10^{3}$ CFU $\mathrm{mL}^{-1}$ downstream of Olsztyn (VII). HPC 22 showed a similar pattern to HPC 37 along the river profile, with no significant differences between the stations (Dunn's test, $p \leq 0.05$ ) except for station VII (downstream of Olsztyn).

During the recording period, FC did not pose a health risk along the upper section of the Łyna River (FC $<1$ CFU $100 \mathrm{~mL}^{-1}$ ). However, FC was progressively increasing in numbers down the river course. An abrupt increase in FC reached $2.5 \times 10^{3} \mathrm{CFU} 100 \mathrm{~mL}^{-1}$ at station VI, where the river receives contaminants from diffuse sources along the town of Olsztyn.
In general, the riverine bacteria developed semigradually over the course of the river. This pattern was disrupted in the urban regions (VII-XIV) by an abrupt increase in apparent bacterial richness and a clear shift in the majority of the nutrients. The input of treated sewage altered the investigated parameters of the water. Our data indicate that the intrinsic factors determining bacterial abundance are man-made pollutants received by the river from urban areas with effluents from wastewater treatment plants. In particular, the sampling station at the Olsztyn center (VI) marks the turning point with the highest average concentrations of apparent bacteria. The VI sampling point is located at a city park, a popular site for recreation for the citizens and tourists. Some authors (e.g., Korzeniewska 2005, Edge and Hill 2007, Wright et al. 2009; Kacar 2011; Daly et al. 2013; GarciaArmisen et al. 2014; Vincy et al. 2015) reported that the contamination of public recreational places with fecal bacteria was mainly caused by pet animals' feces. In this study, only the samples collected at stations I-IV were within the contamination limits recommended by the Bathing Water Directive (2006/7/EC) for recreational waters $\left(<0.5 \times 10^{3} \mathrm{CFU} 100 \mathrm{~mL}^{-1}\right)$. In line with the criteria set out by the Directive, all the water samples collected in the urban sections failed to meet the minimal requirements and were classified in the "poor quality" category.

Multivariate analyses of the water quality

Factor analysis (FA) and principal component analysis (PCA) were accomplished on the standardized data sets for the 14 sampling sites. Factor analysis of the data set outputs a four-component model with $75.36 \%$ of the total variance explained (Fig. 3a; Table 4). The significance of any factor was determined by an eigenvalues $>1.0$ (Fig. 3b). The first component (F1) describes $31 \%$ of the total variance and includes strong loadings ( $>0.75$ ) of $\mathrm{PO}_{4}-\mathrm{P}$ and environmental variables with distance to the headwater and flow (Table 4). COD and $\mathrm{NO}_{2}-\mathrm{N}$ are also related to $\mathrm{F} 1$, but they are noted by moderate loadings. Both parameters have positive relations with the number of bacteria colonies, especially HPC 22 . The values of COD and $\mathrm{NO}_{2}-\mathrm{N}$ increased from the upstream to downstream stations of the Łyna River (Fig. 3a), indicating that water pollution associated with domestic, municipal, and land use activities. This was largely expected because despite the connections of households to 


\section{a}
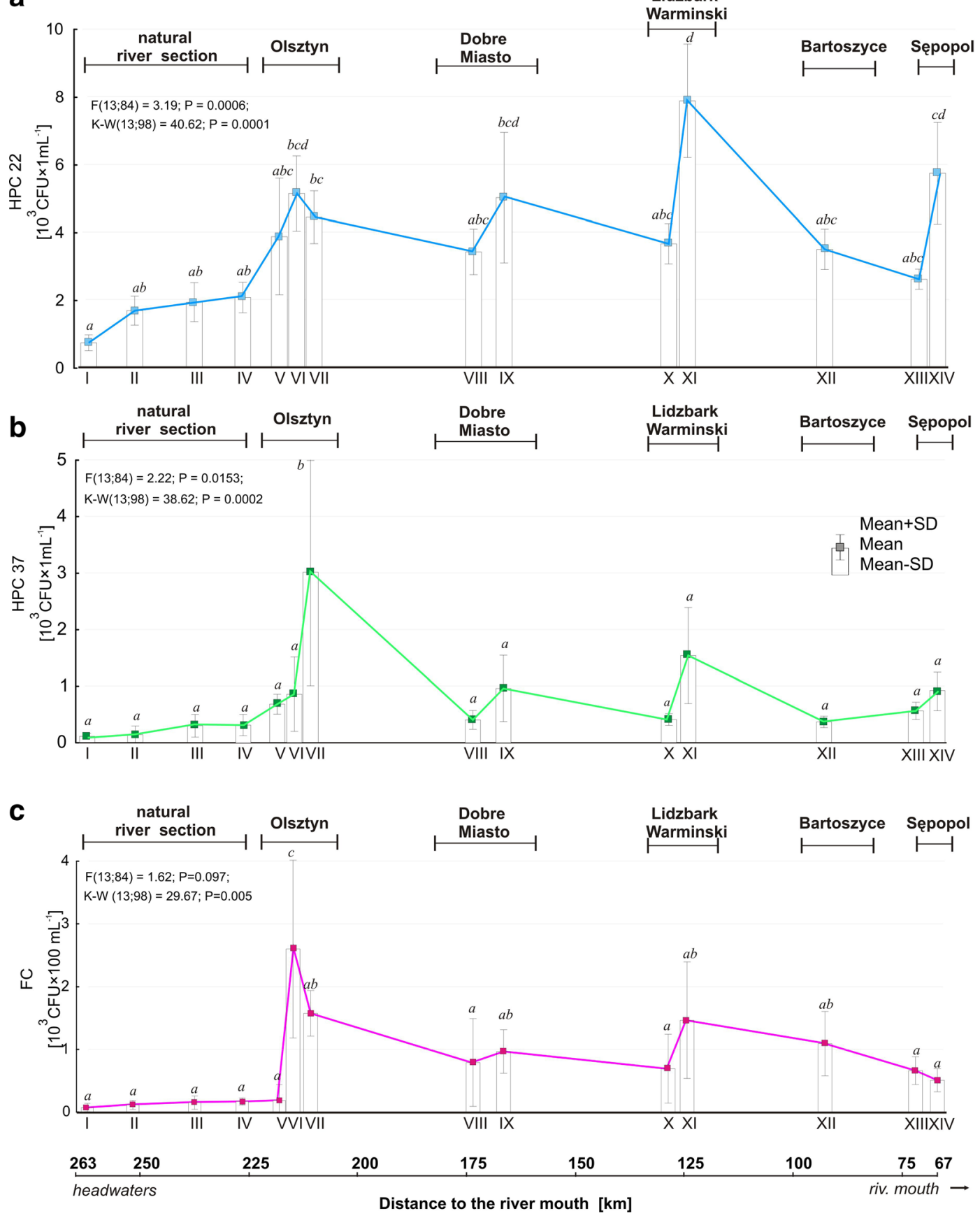

Fig. 2 Longitudinal profiles of the microbiological parameters (mean $\pm \mathrm{SD}$ ) of the water in the Łyna River at sampling sites $I-$ $X I V$. a HPC 22, b HPC 37, and c fecal coliforms (FC). Different

WWTPs, the domestic effluents of unsewered areas and surface runoff from the large, impervious urban areas of Olsztyn and Lidzbark Warmiński discharge their wastewater with rainfall directly into the Łyna letters denote groups of means that are significantly different in the non-parametric Dunn's test at $P \leq 0.05$

River. Thus, heavy rainfalls can be attributed to the increase in FC from non-point sources along, e.g., the Olsztyn center. However, this factor shows a strong relation to the fourth component (F4). 

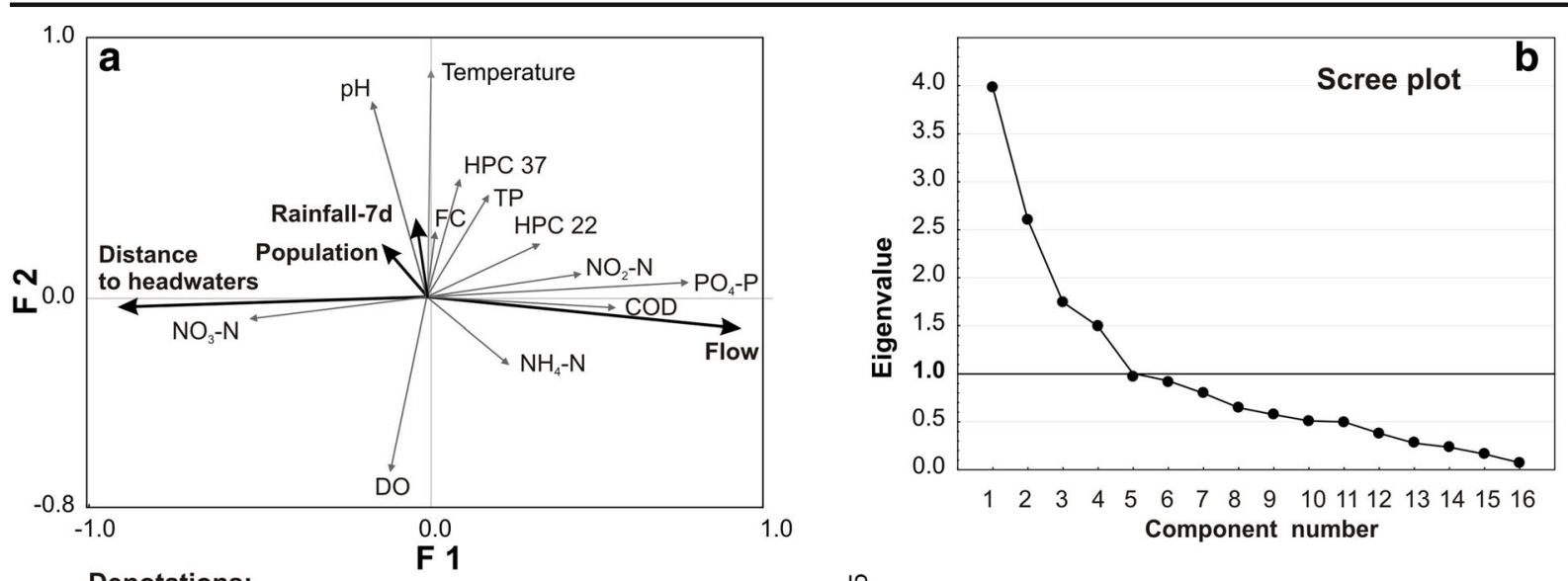

Denotations:

F 1

Component number

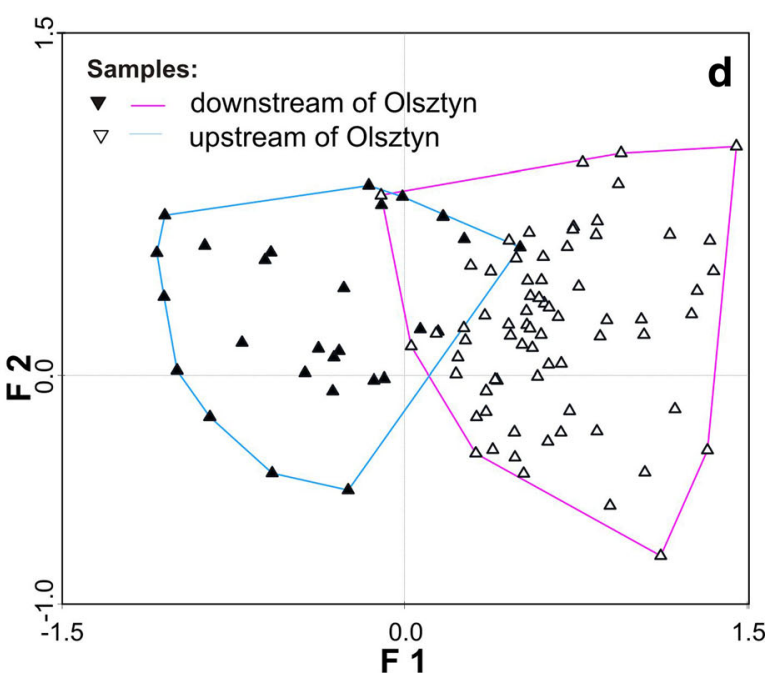

Fig. 3 Results of principal component analysis performed with the environmental variables and water quality data along the Łyna River $(P \leq 0.05)$. a Biplot of significant environmental variables and water quality data related to factor $1(F 1)$ and factor $2(F 2)$. b Scree plot for eigenvalues. $\mathbf{c}$ Pie charts showing the share of each

Factor 2 shows approximately $18.29 \%$ of the total variance (Table 4). It has two parameters with strong positive loadings ( $\mathrm{pH}$ and temperature) and one with moderate negative loading (DO). The loadings of TP and HPC 37 increase with the temperature and preceding rainfalls. Factor 3 shows approximately $16 \%$ of the total variance and has only two parameters with strong significant loadings, which are $\mathrm{NH}_{4}-\mathrm{N}$ and the number of inhabitants, while HPC 22, HPC 37, FC, COD, and $\mathrm{NO}_{2}-\mathrm{N}$ showed weak loadings; thus, this factor attributes pollution to domestic wastewater. Factor 4, with $10 \%$ of the variance, is significantly related to the rainfall sum, which has an important influence on FC counts and the inverse loading of TP.

parameter values in each season. d Plot of the samples' distribution. Two distinct groups of samples have been selected: blue area with black triangles is related to the unpolluted river section, and red area with white triangles denotes the anthropogenically polluted river section

A trend toward higher apparent FC bacterial richness is likely caused by man-made factors rather than environmental factors that partially confirmed the results of Kacar (2011), who found no significant relationships between the fecal indicator bacteria and environmental factors. We argue that point source contamination tends to be directly discharged into river water, generating contamination variability that is often unrelated to runoff variability and meteorological factors. Conversely, diffuse contamination requires transport by means of runoff into surface water (St Laurent and Mazumder 2014). Therefore, the variability in fecal contamination may be more strongly associated with hydrometeorological conditions in watersheds, where contamination is associated with diffuse sources. This can be observed 
Table 4 The factor loadings after the varimax rotation of the water quality data
Values in italics indicate statistically significant scores

*0.30-0.50 (weak); **0.50-0.75 (moderate); $* * *>0.75$ (strong loading)

\begin{tabular}{lcccc}
\hline Parameters & F1 & F2 & F3 & F4 \\
\hline Distance to headwaters $(\mathrm{km})$ & $-0.93^{* * *}$ & -0.04 & 0.06 & 0.03 \\
Population & -0.24 & 0.09 & $0.83^{* * *}$ & -0.08 \\
Flow & $0.92^{* * *}$ & -0.10 & -0.06 & -0.05 \\
Temperature & 0.00 & $0.88^{* * *}$ & -0.04 & 0.06 \\
Rainfall (7-day sum) & -0.03 & 0.27 & 0.02 & $0.86^{* * *}$ \\
$\mathrm{HPC} 22$ & $0.33^{*}$ & 0.21 & $0.43^{*}$ & 0.01 \\
$\mathrm{HPC} 37$ & 0.09 & $0.46^{*}$ & $0.39^{*}$ & -0.22 \\
$\mathrm{FC}$ & 0.01 & 0.21 & $0.43^{*}$ & $0.40^{*}$ \\
$\mathrm{pH}$ & -0.18 & $0.76^{* * *}$ & -0.08 & $0.37 *$ \\
$\mathrm{COD}$ & $0.55^{* *}$ & -0.07 & $0.49^{*}$ & -0.15 \\
$\mathrm{DO}^{*}$ & -0.13 & $-0.68^{* *}$ & -0.16 & 0.17 \\
$\mathrm{PO}_{4}-\mathrm{P}$ & $0.76^{* * *}$ & 0.06 & 0.15 & -0.10 \\
$\mathrm{TP}$ & 0.17 & $0.40^{*}$ & 0.23 & $-0.66^{* *}$ \\
$\mathrm{NH}_{4}-\mathrm{N}$ & 0.23 & -0.25 & $0.70^{* * *}$ & 0.01 \\
$\mathrm{NO}_{2}-\mathrm{N}$ & $0.44^{*}$ & 0.09 & $0.31^{*}$ & 0.18 \\
$\mathrm{NO}_{3}-\mathrm{N}$ & $-0.52^{* *}$ & -0.09 & $-0.47^{*}$ & -0.05 \\
$\%$ Variance & 31.01 & 18.29 & 15.94 & 10.12 \\
$\%$ Of cumulative variance & 31.01 & 49.30 & 65.24 & 75.36 \\
\hline
\end{tabular}

37 occurred mainly during spring and summer (data not shown). This observation might be assigned to higher levels of nutrients, particularly $\mathrm{NH}_{4}-\mathrm{N}, \mathrm{PO}_{4}-\mathrm{P}$, and COD (Fig. 3c), which was also reported by Kacar (2011) for Turkish rivers and for other postglacial rivers in Poland by Gołaś et al. (2008) or Donderski and Wilk (2002). In addition, no clear FC-dominating season can be observed in the pie charts (Fig. 3c).

By looking at the patterns of the water quality parameters along the Łyna longitudinal profile, it becomes possible to compare the 14 sampling stations with each other and visualize their relationships in the form of a dendrogram (Fig. 4). Cluster
Fig. 4 Dendrogram of hierarchical cluster analysis (HCA) for 14 sampling sites along the Kyna River based on the physico-chemical and bacteriological parameters of the water. The clusters are statistically significant when $\mathrm{D}_{\text {link }}$ /

$\mathrm{D}_{\text {max }} * 100<50$

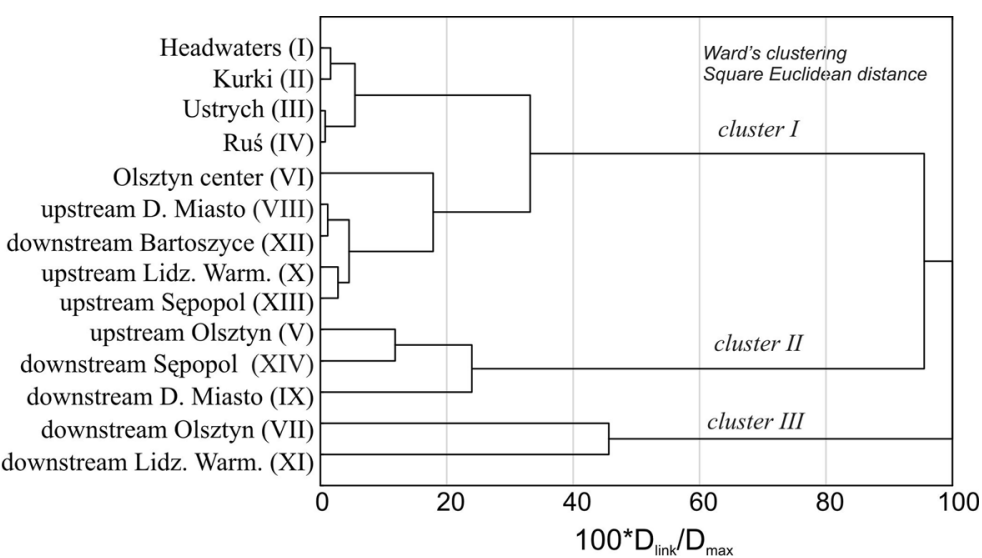


I was identified as a group consisting of stations I to IV (Headwaters $\rightarrow$ Ruś) and the stations located at Olsztyn's center (VI) and downstream of the towns (VIII, XII, X, XIII). In cluster I, the group of stations corresponds to the least polluted river water. Within cluster II, the sites located at upstream Olsztyn (V), downstream Sępopol (XIV), and downstream Dobre Miasto (IX) were the most similar to each other. The inclusion of the sampling station farthest downstream (downstream Secpopol) in cluster II suggests the selfpurification and assimilative capacity of the river. Cluster III formed the group consisting of the most polluted sites: downstream Olsztyn (VII) and Lidzbark Warmiński (XI). These stations receive pollution mostly from domestic wastewater and WWTP effluents located in the city areas (Fig. 4).

In upper reach of the river (headwater area), a portion of nutrients removed from the water column is removed permanently via denitrification, but the majority are only delayed temporarily, e.g., via assimilatory uptake (Mulholland et al. 2008), and are eventually available for export downstream the river. Comparative analyses of water quality change along natural (upstream) and urban (downstream) sections of the Eyna River have led us to conclusions supporting the outcomes of the study performed by Seitzinger et al. (2002) and Reisinger et al. (2015) that the nutrient drawdown in the downstream river section is more efficient at removing nutrients per unit stream length compared to the headwater section.

Our results showed that the relative influences of five urban areas and natural environmental factors on the ecosystem of one river showed that urbanization was most likely the primary determinant of river water quality deterioration. The established relationships between five consecutive towns and hydrochemical and microbiological conditions, however, did not indicate a specific threshold of effects but showed that the spatial distribution of impervious surfaces and sanitary infrastructure has a direct impact on the longitudinal changes in water quality parameters of the Łyna River.

Due to spatial heterogeneity of land use, monitoring of the changes in water quality, retention, and export of pollutants along the urban river continuum is critical for predicting downstream alterations of ecosystem functions, managing pollutant exports, and finally assessing the needs of restoration activities at a scale river of the river as its watershed.

\section{Conclusions}

Our study investigated the influence of serial urban areas on the physico-chemical water quality parameters and bacterial community along the Łyna River in northern Poland, a representative for low-gradient postglacial watercourses in the temperate climatic zone. The hydrochemical and microbiological profiling of the Łyna River established two river sections with different levels of water quality: (1) the upper, unpolluted section from the headwaters to Olsztyn and (2) the lower section with anthropogenic influences, mostly from urban areas. In this study, we demonstrated that the water quality in the upper region, in terms of both the physico-chemical and microbiological parameters, may be considered as a benchmark of the geochemical background for the assessment of water chemistry conditions in the context of the entire region.

Abrupt changes in the physico-chemical and microbiological parameters of the water have been found downstream of the five towns that the Lyna River passes. The spatial and temporal variations of the quality and microbiology of the river water is the hallmark of urban pollution. The application of PCA and cluster analysis allowed for the grouping of river water sampling stations based on the seasonal and spatial criteria. The rotated principal components have demonstrated that (i) the nutrient contents in the upper region are more seasonal and climate dependent, thus pointing to their natural origin (geochemical background) and that (ii) pollution from organic matter, nutrients, and microorganisms originates from anthropogenic sources, mainly as municipal wastewater, which is more resistant to hydrology and seasonal variations.

Our conclusion is that cities are no longer isolated elements in the landscape but are parts of hydrologically connected ecosystems that encompass large areas of the landscape into one "urban river continuum." The present-day management of an urban river continuum requires investigating the cumulative and/or overlapping effects of all urban areas as pollutant sources and the alternating fluxes and flow paths of materials and energy into the receiving water downstream. Considering the river as a medium that transfers a variety of pollutants, understanding the impacts of a single urban area will be equally as important as the urban river continuum in predicting the impacts of man-made pollutants on river water quality. 
The quantitative characteristics of the physicochemical parameters and the abundance of bacteria along a longitudinal profile of a river obtained in the research procedure have made it possible to define a base for the factors underlying the functioning of the Łyna River as a present-day regularity in postglacial areas situated in the temperate climatic zone.

Open Access This article is distributed under the terms of the Creative Commons Attribution 4.0 International License (http://creativecommons.org/licenses/by/4.0/), which permits unrestricted use, distribution, and reproduction in any medium, provided you give appropriate credit to the original author(s) and the source, provide a link to the Creative Commons license, and indicate if changes were made.

\section{References}

APHA (American Public Health Association) (1998). Standard method for the examination of water and wastewater (19th ed.). Washington DC: American Public Health Association.

Begum, S., Adnan, M., McClean, C. J., \& Cresser, M. S. (2016). A critical re-evaluation of controls on spatial and seasonal variations in nitrate concentrations in river waters throughout the River Derwent catchment in North Yorkshire, UK. Environmental Monitoring and Assessment, 188, 305. doi:10.1007/s10661-016-5305-4.

Brion, N., Verbanck, M. A., Bauwens, W., Elskens, M., Chen, M., \& Servais, P. (2015). Assessing the impacts of wastewater treatment implementation on the water quality of a small urban river over the past 40 years. Environmental Science and Pollution Research, 22, 12720-12736. doi:10.1007/s11356-015-4493-8.

Brooks, B. W., Riley, T. M., \& Taylor, R. D. (2006). Water quality of effluent-dominated ecosystems: ecotoxicological, hydrological and management considerations. Hydrobiologia, 556, 365-379.

Cymes, I., \& Glińska-Lewczuk, K. (2016). The use of water quality indices (WQI and SAR) for multipurpose assessment of water in dam reservoirs. Journal of Elementology, 21(4), 1211-1224. doi:10.5601/jelem.2016.21.2.1200.

Daly, E., Kolotelo, P., Schang, C., Osborne, C. A., Coleman, R., Deletic, A., \& McCarthy, D. T. (2013). Escherichia coli concentrations and loads in an urbanised catchment: the Yarra River, Australia. Journal of Hydrology, 497, 51-61.

Daniel, M. H. B., Montebelo, A. A., Bernardes, M. C., Ometto, J. P. H. B., DeCamargo, P. B., Krusche, A. V., Ballester, M. V., Victoria, R. L., \& Martinelli, L. A. (2002). Effects of urban sewage on dissolved oxygen, dissolved inorganic and organic carbon, and electrical conductivity of small streams along a gradient of urbanization in the Piracicaba River basin. Water, Air, \& Soil Pollution, 136, 189-206.

Directive 2006/7/EC of the European Parliament and of the Council of 152006 concerning the management of bathing water quality. Official Journal of the European Union, L64, $37-51$.
Donderski, W., \& Wilk, I. (2002). Bacteriological studies of water and bottom sediments of the Vistula River between Wyszogród and Torun. Polish Journal of Environmental Studies, 1, 33-40.

dos Santos Simoes, F., Moreira, A. B., Bisinoti, M. C., Gimenez, S. M. N., \& Yabe, M. J. S. (2008). Water quality index as a simple indicator of aquaculture effects on aquatic bodies. Ecological Indicators, 8(5), 476-484.

Edge, T. A., \& Hill, S. (2007). Multiple lines of evidence to identify the sources of fecal pollution at a fresh water beach in Hamilton Harbour, Lake Ontario. Water Research, 41, 3585-3594.

Elmore, A. J., \& Kaushal, S. S. (2008). Disappearing headwaters: patterns of stream burial due to urbanization. Frontiers in Ecology and the Environment, 6, 308-312.

Garcia-Armisen, T., Inceoĝlu, Ö., Ouattara, N. K., Anzil, A., Verbanck, M. A., Brion, N., \& Servais, P. (2014). Seasonal variations and resilience of bacterial communities in a sewage polluted urban river. PloS One, 9(3), e92579. doi:10.1371/journal.pone.0092579.

Glińska-Lewczuk, K. (2006). Effect of land use and lake presence on chemical diversity of the Łyna River system. Polish Journal of Environmental Studies, 15(2), 259-269.

Glińska-Lewczuk, K., \& Burandt, P. (2011). Effect of river straightening on the hydrochemical properties of floodplain lakes: observations from the Łyna and Drwęca Rivers, N Poland. Ecological Engineering, 37, 786-795.

Gołaś, I., Zmysłowska, I., Harnisz, M., Korzekwa, K., Skowrońska, A., Teodorowicz, M., Górniak, D., Gros, M., \& Brzozowa, S. (2008). Nitrogen cycle bacteria in the waters of the Drwęca River. Polish Journal of Environmental Studies, 17(2), 215-225.

Gotkowska-Płachta, A., Gołaś, I., Korzeniewska, E., Koc, J., Rochwerger, A., \& Solarski, K. (2016). Evaluation of the distribution of fecal indicator bacteria in a river system depending on different types of land use in the southern watershed of the Baltic Sea. Environmental Science and Pollution Research, 23, 4073-4085.

GUS (2012). Means of production in agriculture in the 2010/2011 farming year. Statistical information and elaborations. CENTRAL STATISTICAL OFFICE Warszawa 2011. Online: www.stat.gov.pl.

Hatt, B. E., Fletcher, T. D., Walsh, C. J., \& Taylor, S. L. (2004). The influence of urban density and drainage infrastructure on the concentrations and loads of pollutants in small streams. Environmental Management, 34, 112-124.

HEC-RAS River Analysis System (2010). User's manual, version 4.1. Davis, California: U.S. Army Corps of Engineers Hydrologic Engineering Center.

Heidenwag, I., Langheinrich, U., \& Lüderitz, V. (2001). Selfpurification in upland and lowland streams. Acta Hydrochimica et Hydrobiologica, 29(1), 22-33.

House, M. A. (1989). A water quality index for river management. Journal of the Institute of Water \& Environmental Management, 3, 336-344.

IMWM (Institute of Meteorology and WaterManagement) (2012) http://www.bodc.ac.uk/data/information_and inventories/edmed/org/193.

Journal of Laws of 2006, no. 137, item 984, as amended Regulation of the Polish Minister of Environment of 24 
July 2006 on conditions to be met for the introduction of sewage into the water or ground and on substances particularly harmful to the aquatic environment.

Kacar, A. (2011). Analysis of spatial and temporal variation in the levels of microbial fecal indicators in the major rivers flowing into the Aegean Sea, Turkey. Ecological Indicators, 11, 1360-1365.

Kaushal, S. S., \& Belt, K. T. (2012). The urban watershed continuum: evolving spatial and temporal dimensions. Urban Ecosystems, 15, 409-435.

Korzeniewska, E. (2005). Escherichia coli and some groups of potentially pathogenic bacteria in the Lake Wigry off shore water. Archives of Environmental Protection, 31(2), 69-84.

Liu, C. W., Lin, K. H., \& Kuo, Y. M. (2003). Application of factor analysis in the assessment of groundwater quality in a Blackfoot disease area in Taiwan. Science of the Total Environment, 313, 77-89.

Mallin, M. A., Johnson, V. L., \& Ensign, S. H. (2016). Comparative impacts of stormwater runoff on water quality of an urban, a suburban, and a rural stream. Environmental Monitoring and Assessment, 159, 475-491.

Mulholland, P. J., Helton, A. M., Poole, G. C., Hall, R. O., Hamilton, S. K., Peterson, B. J., Tank, J. L., Ashkenas, L. R., Cooper, L. W., Dahm, C. N., Dodds, W. K., Findlay, S. E. G., Gregory, S. V., Grimm, N. B., Johnson, S. L., McDowell, W. H., Meyer, J. L., Valett, H. M., Webster, J. R., Arango, C. P., Beaulieu, J. J., Bernot, M. J., Burgin, A. J., Crenshaw, C. L., Johnson, L. T., Niederlehner, B. R., O’Brien, J. M., Potter, J. D., Sheibley, R. W., Sobota, D. J., \& Thoma, S. M. (2008). Nature, 452, 202-205. doi:10.1038/nature06686.

Obolewski, K. (2013). Use of macrozoobenthos for biological assessment of water quality in oxbow lakes of varying hydrological connectivity to the main river channel in the example of Łyna River valley. Ochrona Środowiska, 35, 19-26.

Potasznik, A., \& Szymczyk, S. (2015). Magnesium and calcium concentrations in the surface water and bottom deposits of a river-lake system. Journal of Elementology, 20(3), 677-692. doi:10.5601/jelem.2015.20.1.788.

Reisinger, A. J., Tank, J. L., Rosi-Marshall, E. J., HallJr, R. O., \& Baker, M. A. (2015). The varying role of water column nutrient uptake along river continua in contrasting landscapes. Biogeochemistry, 125, 115. doi:10.1007/s10533-015-0118-z.

Schoonover, J. E., Lockaby, B. G., \& Helms, B. S. (2006). Impacts of land cover on stream hydrology in the West Georgia Piedmont. Journal of Environmental Quality, 35, 2123-2131.

Seitzinger, S. P., Styles, R. V., Boyer, E. W., Alexander, R. B., Billen, G., Howarth, R. W., Mayer, B., \& Breemen, N. V. (2002). Nitrogen retention in rivers: model development and application to watersheds in the northeastern U.S.A. Biogeochemistry, 57(58), 199-237.

Servais, P., Garcia-Armisen, T., George, I., \& Billen, G. (2007). Fecal bacteria in the rivers of the Seine drainage network
(France): sources, fate and modeling. Science of the Total Environment, 375(1-3), 152-167.

Shrestha, S., \& Kazama, F. (2007). Assessment of surface water quality using multivariate statistical techniques: a case study of the Fuji River Basin, Japan. Environmental Modelling \& Software, 22(4), 464-475.

Singh, K. P., Malik, A., \& Sinha, S. (2005). Water quality assessment and apportionment of pollution sources of Gomti river (India) using multivariate statistical techniques: a case study. Analytica Chimica Acta, 538, 355-374.

Spänhoff, B., Bischof, R., Böhme, A., Lorenz, S., Neumeister, K., Nöthlich, A., \& Küsel, K. (2007). Assessing the impact of effluents from a modern wastewater treatment plant on breakdown of coarse particulate organic matter and benthic macroinvertebrates in a lowland river. Water, Air, \& Soil Pollution, 180, 119-129.

St Laurent, J., \& Mazumder, A. (2014). Influence of seasonal and inter-annual hydrometeorological variability on surface water fecal coliform concentration under varying land-use composition. Water Research, 48, 170-178.

ter Braak, C. J. F., \& Šmilauer, P. (2002). Reference manual and Cano Draw for Windows user's guide: software for canonical community ordination (version 4.5). Ithaca, NY, USA: Microcomputer Power.

US Environmental Protection Agency (US EPA) (1986). Quality criteria for water. Washington DC: Water. EPA 440/5-86001. Office of Water Regulations and Standards 20460.

Vaikasas, S., \& Dumbrauskas, A. (2010). Self-purification process and retention of nitrogen in floodplains of River Nemunas. Hydrology Research, 41(3-4), 338-345.

Vincy, M. V., Brilliant, R., \& Pradeepkumar, A. P. (2015). Prevalence of indicator and pathogenic bacteria in a tropical river of Western Ghats, India. Applied Water Science. doi:10.1007/s13201-015-0296-9.

Walsh, C. J., Roy, A. H., Feminella, J. W., Cottingham, P. D., Groffman, P. M., \& Morgan, R. P. (2005). The urban stream syndrome: current knowledge and the search for a cure. $J N$ Am Benthol Soc, 24, 706-723.

Walsh, C. J., Fletcher, T. D., \& Burns, M. J. (2012). Urban stormwater runoff: a new class of environmental flow problem. PloS One, 7(9), e45814.http://doi.org/10.1371/journal.pone.0045814

Walsh, C. J., Booth, D. B., Burns, M. J., Fletcher, T. D., Hale, R. L., Hoang, L. N., Livingston, G., Rippy, M. A., Roy, A. H., Scoggins, M., \& Wallace, A. (2016). Principles for urban stormwater management to protect stream ecosystems. Freshwater Science, 35, 398-411.

Wohlsen, T. D. (2011). Comparative evaluation of chromogenic agar CM1046 and mFC agar for detection of E. coli and thermotolerant coliform bacteria from water samples. Letters in Applied Microbiology, 53, 155-160.

Wright, M. E., Solo-Gabriele, H. M., Elmir, S., \& Fleming, L. E. (2009). Microbial load from animal feces at a recreational beach. Marine Pollution Bulletin, 58(11), 1649-1656.

Zar, J. H. (1984). Biostatistical analysis (Vol. 718). Englewood Cliffs, NY: Prentice-Hall. 